\title{
Dental and Periodontal Infection
}

National Cancer Institute

\section{Source}

National Cancer Institute. Dental and Periodontal Infection. NCI Thesaurus. Code C36069.

An infectious process that affects the teeth and/or the periodontal tissues. 